University of South Carolina

Scholar Commons

1987

\title{
A 3-D Gravity Tectonic Study of Ita Mai Tai Guyot: An Uncompensated Seamount in the East Mariana Basin
}

Bruce S. Wedgeworth

James N. Kellogg

University of South Carolina - Columbia, kellogg@geol.sc.edu

Follow this and additional works at: https://scholarcommons.sc.edu/geol_facpub

Part of the Earth Sciences Commons

\section{Publication Info}

Published in Geophysical Monograph Series, ed. B. H. Keating, P. Fryer, R. Batiza, G. W. Boehlert, Volume 43, 1987, pages 73-84.

Wedgeworth, B. S. \& Kellogg, J. N. (1987). A 3-D gravity tectonic study of Ita Mai Tai Guyot: an uncompensated seamount in the East Mariana Basin, in Seamounts, Islands, and Atolls. Geophysical Monograph Series, 43, 73-84.

(C) Geophysical Monograph Series 1987, American Geophysical Union

This Article is brought to you by the Earth, Ocean and Environment, School of the at Scholar Commons. It has been accepted for inclusion in Faculty Publications by an authorized administrator of Scholar Commons. For more information, please contact digres@mailbox.sc.edu. 


\title{
A 3-D GRAVITY-TECTONIC STUDY OF ITA MAI TAI GUYOT: AN UNCOMPENSATED SEAMOUNT IN THE EAST MARIANA BASIN
}

\author{
Bruce Wedgeworth ${ }^{1}$ and James Kellogg ${ }^{2}$
}

Hawaii Institute of Geophysics, Honolulu, Hawaii 96822

Abstract. Ita Mai Tai is a large, locally uncompensated seamount on the eastern edge of the East Mariana Basin. A large positive gravity anomaly of $254 \mathrm{mgal}$ characterizes the summit and a low of -69 mgal, the surrounding moat. Using polygonal prisms to approximate the bathymetry, the observed gravity was inverted to calculate an average density of $2.59 \mathrm{~g} / \mathrm{cm}^{3}$ for the seamount. Observed-calculated gravity residuals are reduced by including the flanking sedimentary basins and a dense volcanic conduit. The drill sites from DSDP Legs 20 and 89 describe a volcanic edifice formed in the Aptian/Albian on Jurassic/Cretaceous crust. The volcanism is recorded in volcanoclastic and epiclastic deposits in the basins nearby. The guyot was covered initially by a succession of reefal and lagoonal sediments followed by a thick mantling of pelagic sediments after it subsided. Gravity models that adequately match the calculated and observed data sets for Ita Mai Tai show little crustal thickening, suggesting that Ita Mai Tai is almost completely locally uncompensated.

\section{Introduction}

A major goal in the application of the theory of plate tectonics in the Pacific has been determining the age and location of the oldest part of the Pacific plate. An attempt to reach this objective was made in 1971 when DSDP Leg 20 drilled Site 199 (Fig. 2) in the East Mariana Basin (Fig. 1). It was anticipated that Jurassic lithosphere would be encountered [Larson, 1976; Hilde et al., 1977; Shipley et al., 1983; and others]. Unfortunately, deep water drilling difficulties prevented this primary objective from being reached, and an alternate site was chosen farther east in a cluster of shallow seamounts between the Marshall and Magellan seamount chains (Fig. 1). Three holes were drilled at Sites 200,201 and 202 on one of these seamounts located at $12^{\circ} 45^{\prime} \mathrm{N}, 156^{\circ} 45^{\prime} \mathrm{E}$ (Fig. 2). This seamount was given the informal name Ita Mai Tai Guyot by Bruce Heezen which means "no damn good" in Tahitian [M. Tharp, pers. comm., 1984], possibly because basement was not reached. A second unsuccessful at teinpt to reach Jurassic basement was made in 1982 when DSDP Leg 89 drilled Site 585 just north of Ita Mai Tai. Other cruises across Ita Mai Tai include those of Conrad 1205, a Soviet cruise DDM05 in 1971, and Vema 3401 in 1977.

In 1981 the Hawaii Institute of Geophysics research vessel Kana

\footnotetext{
1 Now at Harding Lawson Associates, Honolulu, Hawaii

2 Now at Department of Geological Sciences, University of South Carolina, Columbia, South Carolina
}

Copyright 1987 by the American Geophysical Union.
Keoki surveyed Ita Mai Tai (Fig. 2) and other charted and uncharted seamounts in the central and western Pacific collecting bathymetric, gravimetric, magnetic, petrologic and seismic reflection profiling data.

The purpose of this study is to compile and analyze the geophysical data to determine the crustal structure of Ita Mai Tai, its degree of isostatic compensation, and its tectonic history. In order to construct accurate density models it was necessary to have as much information as possible on the bathymetry, sediment distribution, and geology of Ita Mai Tai. Therefore, these topics will be discussed before the section on gravity studies.

\section{Regional Framework}

There is a striking dichotomy in morphology and structure between the Eastern Pacific and the Western Pacific (Fig. 1). The picture in the Eastern Pacific seems relatively simple. The seafloor there is characterized by linear island chains with straightforward age progressions, large fracture zones, and simple magnetic lineations. By contrast, the seafloor in the Western Pacific is a complicated collection of large clusters of seamounts and oceanic plateaus.

There have been several hypotheses advanced to explain the distribution of these western Pacific seamounts. The Wilson-Morgan "hotspot" hypothesis for the origin of seamounts predicts linear chains with a progressive age of formation. A second hypothesis is that there was a period of mid-plate volcanism in the Cretaceous during which a widespread area of the western Pacific lithosphere was thinned by a large thermal event [Menard 1964; Schlanger and Premoli-Silva, 1981; Menard, 1984]. Seamounts formed by this mechanism would be expected to show a random distribution, simultaneous regional uplift, and variable paleolatitudes of formation. A third hypothesis is that these seamounts were formed near ridge crests and transform faults. The first and third hypotheses are not necessarily mutually exclusive. (Iceland, the Galapagos and the Mid-Pacific Mountains are possible examples of both mechanisms at work). Seamounts formed near ridge crests should have ages similar to the age of the crust on which they were erupted, a topography reflecting a rectilinear character, and be locally compensated.

Ita Mai Tai, a typical western Pacific seamount, is located on the eastern side of the Mariana Basin. The East Mariana Basin is bordered by the Magellan Seamounts to the north, the Marshall Islands to the east, the Caroline Islands to the south, and the Mariana Trench to the west. The basin is also quite far from well defined magnetic anomaly lineations. The Japanese magnetic lineations are $1500 \mathrm{~km}$ to the northwest, the Hawailan magnetic lineations about $1000 \mathrm{~km}$ to the northeast, the Nauru magnetic lineations almost $1000 \mathrm{~km}$ to the southeast, and the Phoenix magnetic lineations more than $1500 \mathrm{~km}$ 


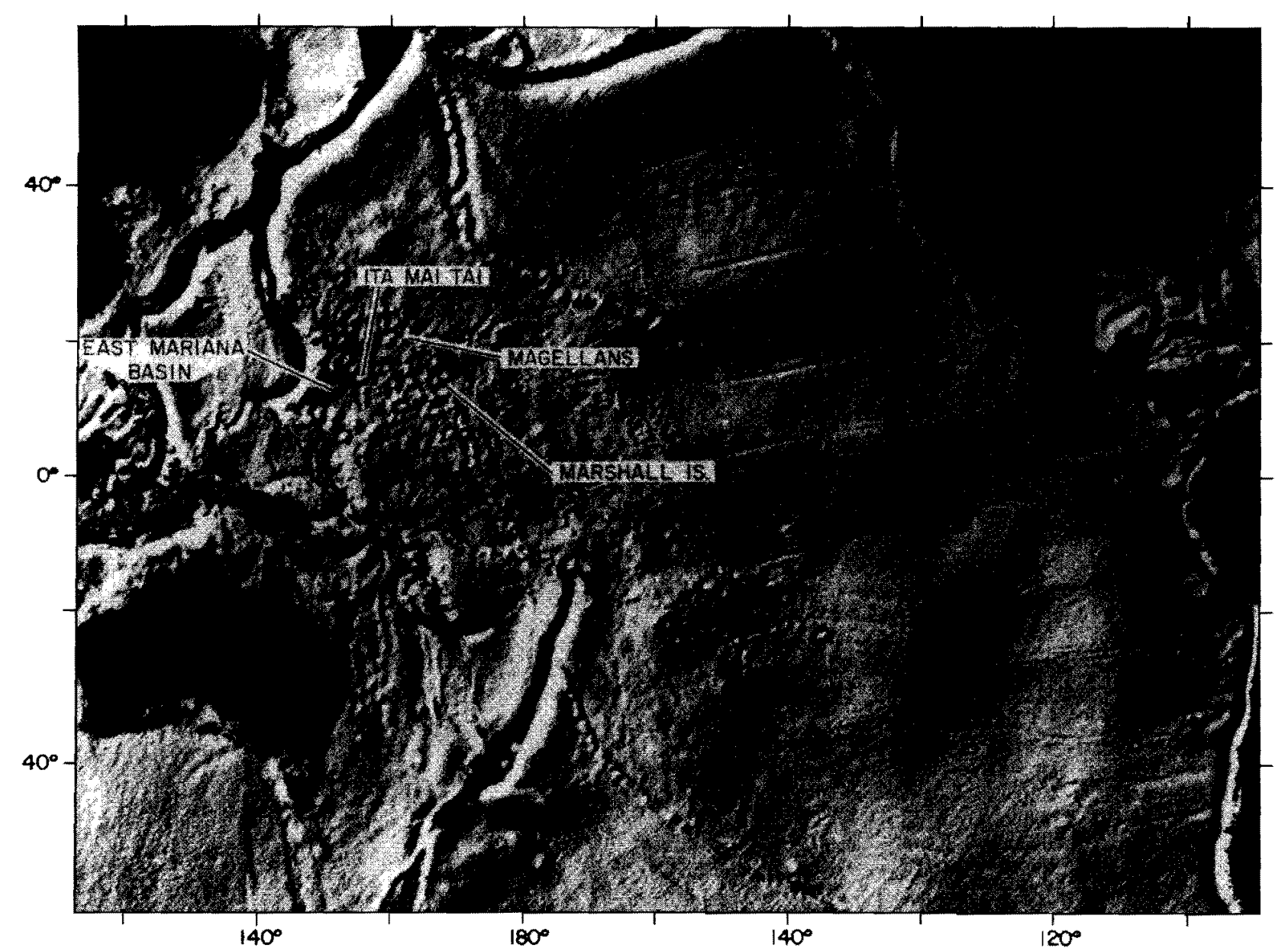

Fig. 1. Gravity image of the Pacific Ocean Basin based upon all Seasat and Geos-3 altimeter data (J. G. Marsh, unpublished data, Code 621, NASA/Goddard Space Flight Center, Greenbelt, Maryland 20771). Data were gridded on a $1 / 8^{\circ}$ grid. A geoid of degree and order 12 has been removed in order to enhance the shorter wave-length features. Ita Mai Tai and nearby seamounts stand out as positive anomalies.

to the east-southeast. The region between these lineations including the East Mariana Basin is characterized by low amplitude or ambiguous magnetic lineations usually referred to as the Jurassic Magnetic Quiet Zone which make determining the age of seafloor near Ita Mai Tai a problem.

Shipley et al. (1983) assumed a half spreading rate of $4.7 \mathrm{~cm} / \mathrm{yr}$ and extrapolated from M-25 in the Phoenix lineations to estimate the age of the crust in the East Mariana Basin as Jurassic. Paleomagnetic data from DSDP sites 585,289 , and 462 indicate that the western Central Pacific had $4.5 \mathrm{~cm} / \mathrm{yr}$ of northward drift between the Aptian and Campanian [Scientific Party, Leg 89, 1983]. Other authors have also concluded that the oldest oceanic crust in this part of the western Pacific is Jurassic [Larson and Chase, 1972; Hilde et al., 1976]. However, Kroenke, in Hilde et al. (1977), has suggested that there was an episode of generally north-south intra-plate spreading starting $110 \mathrm{MyBP}$ and that the crust presently beneath the East Mariana Basin is upper Cretaceous. The lowest section of Site 585 encountered late Aptian hyaloclastite- rich turbidite and debris flows from the surrounding subaerial volcanoes. This site stopped just short of sampling the oceanic basement, and thus there is still no direct evidence for the age of the basin.

\section{Seamount Morphology}

The bathymetric map of Ita Mai Tai Guyot is shown in Figure 2. Ita Mai Tai rises $4600 \mathrm{~m}$ from abyssal depths of around $6000 \mathrm{~m}$ to a minimum depth of $1402 \mathrm{~m}$. The height is considerably greater than the average relief of $1 \mathrm{~km}$ found for a survey of 6530 Pacific seamounts [Udintsev and others, 1976]. The shape of the seamount is subconical. An ' $L$ ' shaped flank ridge extends to the west and turns to the south toward other seamounts in the chain. The basal diameter measures approximately $90 \mathrm{~km}$ and covers some $6400 \mathrm{~km}^{2}$, which is much greater than the mean of north Pacific volcanoes [Batiza, 1982].

The summit area is quite uniform and flat. A break in slope occurs at about $2200 \mathrm{~m}$ below which the slope of the upper flanks is as steep as $35^{\circ}$. Gradually the slope decreases to average $9-10^{\circ}$ on the lower flanks, a value comparable with that of subaerial volcanoes [Lonsdale and Spiess, 1979]. The northern and southeastern flanks are bordered by a shallow depression or moat as outlined by the 6100 m contour.

\section{Sedimentary Basin Stratigraphy}

The shapes and depths of the sediment filled basins to the north and southeast (Profiles A, B and C) (Fig. 2) were determined from 
A

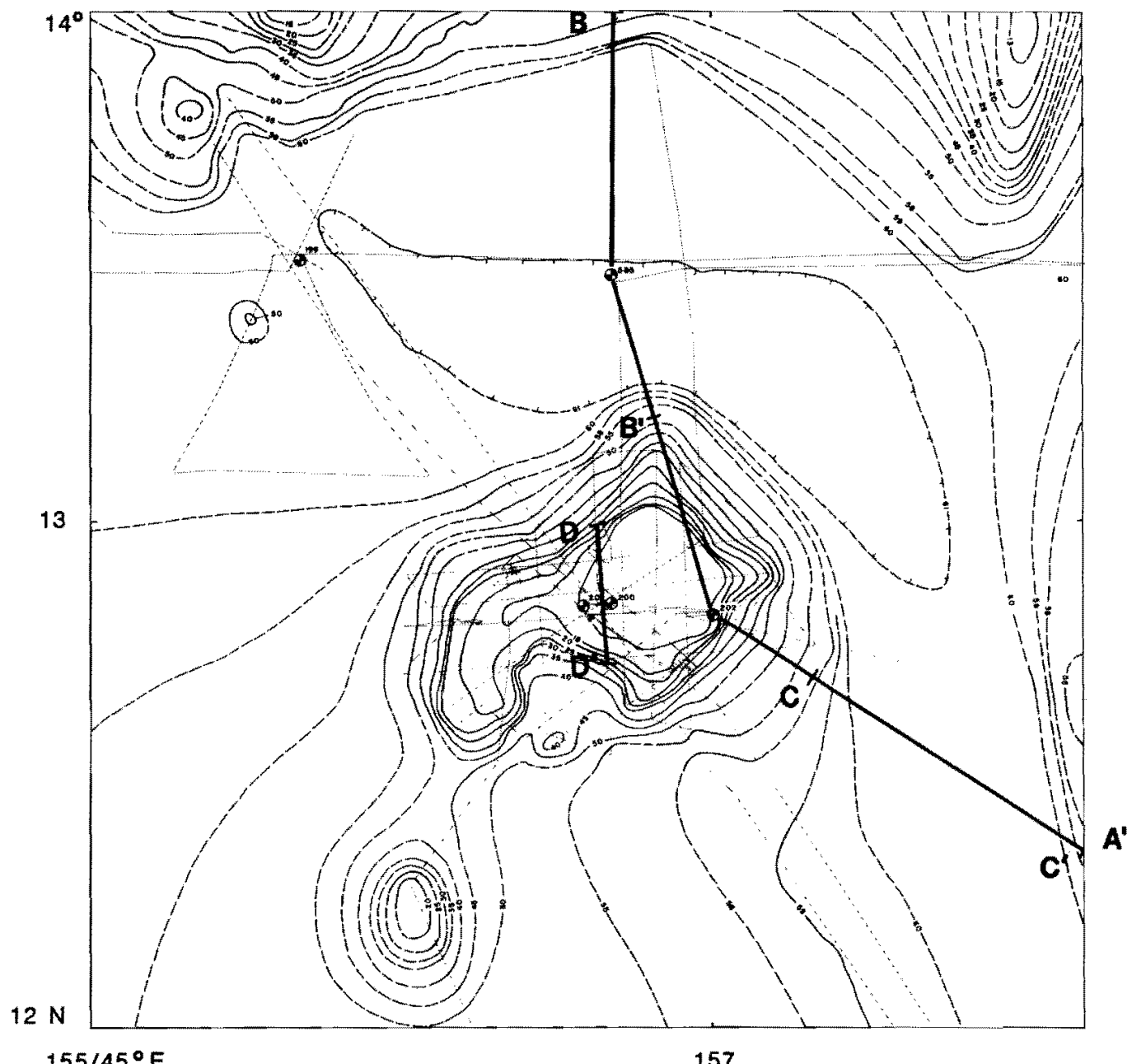

$155 / 45^{\circ} \mathrm{E}$

157

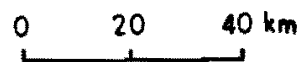

CONTOURS IN METERS $\times 100$

Fig. 2. Bathymetry of Ita Mai Tai Guyot. Track lines are indicated by dotted lines. Seismic cross-sections and five DSDP sites are also indicated.

HIG and DSDP Leg 89 airgun seismic reflection records. The shapes and depths of the pelagic cap units (Profile D) and the northern basin (Profile B) were determined from HIG airgun seismic reflection records. The locations of those profiles selected for this study are shown in Figure 2.

Profile A-A' (Fig. 3 ) is a complete transect of Ita Mai Tai from north to southeast. It includes a seamount $140 \mathrm{~km}$ to the north, a deep sediment filled basin to the north, and another basin to the southeast. The most interesting aspect of this profile is the apparent difference in the depths to acoustic basement in the two basins. The northern hasin appears to be much deeper than the southeastern basin.

Profile B-B' (Fig. 4) completely crosses the northern basin shown on Figure 3. The basin is approximately $73 \mathrm{~km}$ wide at this point and the sea floor is $6100 \mathrm{~m}$ deep. DSDP Site 585 is located about mid-point. The two-way traveltime through the sediments to the floor of the basin is approximately one full second. Five lithologic units in the drilling record are depicted and labeled in the figure. The velocity of each of the lithologic units, their travel-times and maximum thicknesses, are based on closely spaced velocity and density measurements from the drilling record of Site 585 [Scientific Party, Leg 89, 1983] and are shown in Table 1.

The unit thicknesses were independently estimated from HIG airgun seismic reflection records over the northern basin. Acoustic basement begins at about 9 seconds of two-way traveltime or $6900 \mathrm{~m}$. The sediments in the basin are about $900 \mathrm{~m}$ thick. The thickest layer, a section containing volcaniclastic turbidites and debris flows (Unit VI), is also the lowest (Fig. 4). There is an especially strong reflector near 8.4 seconds that extends all the way across the section. This has been interpreted as the top of Unit II, where a large density contrast of $0.4 \mathrm{gm} / \mathrm{cm}^{3}$ is encountered between recent clays and oozes and the Eocene chalks, limestones, cherts and ash beds.

Bright reflectors close to Ita Mai Tai between 8.3 and 8.4 seconds 

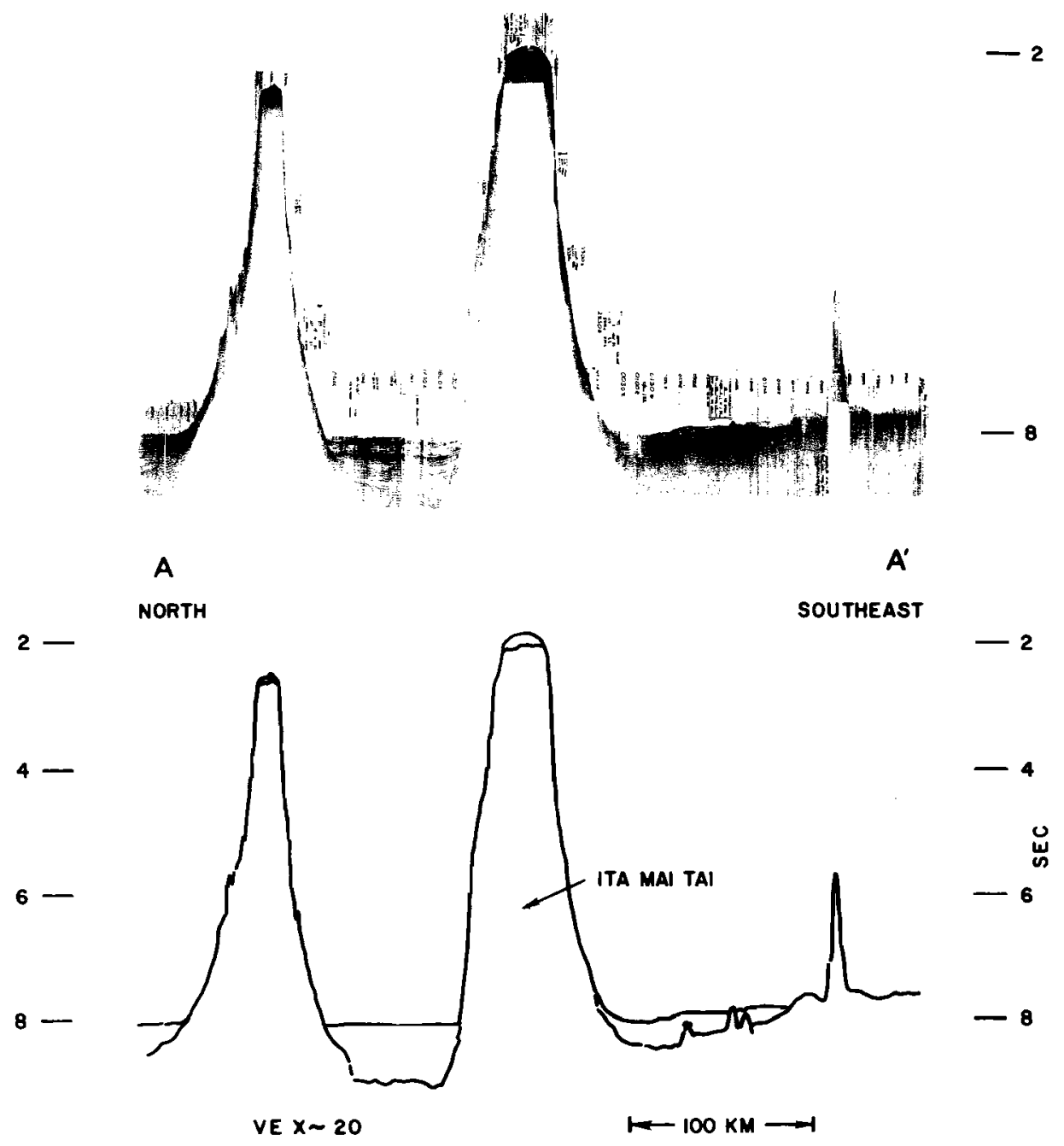

Fig. 3. (a) Photo of airgun seismic reflection record across Ita Mai Tai during DSDP Leg 89 crossing. (b) Line drawing showing the basin depths on either side of Ita Mai Tai. See Figure 2 for location of transect.

TABLE 1. DSDP Leg 89, Site 585 Drilling Record

Velocity Traveltime Maximum

$(\mathrm{km} / \mathrm{s}) \quad(\mathrm{s}) \quad$ Thickness

\begin{tabular}{|c|c|c|c|}
\hline & & & (m) \\
\hline Unit I & 1.50 & 0.17 & 256 \\
\hline \multicolumn{4}{|l|}{ Clay, nannofossil ooze } \\
\hline \multicolumn{4}{|l|}{ Pleistocene } \\
\hline Unit II & 1.89 & 0.08 & 143 \\
\hline \multicolumn{4}{|l|}{$\begin{array}{l}\text { Nannofossil chalk, } \\
\text { zeolitic claystone }\end{array}$} \\
\hline \multicolumn{4}{|l|}{ M. Eocene-Maas. } \\
\hline Units III + IV & 2.01 & 0.04 & 86 \\
\hline \multicolumn{4}{|l|}{$\begin{array}{l}\text { Zeolitic claystone, } \\
\text { chert }\end{array}$} \\
\hline \multicolumn{4}{|l|}{ Maas.-Campanian } \\
\hline Unit $\mathrm{V}$ & 2.01 & 0.05 & 105 \\
\hline \multicolumn{4}{|l|}{$\begin{array}{l}\text { Zeolitic claystone, } \\
\text { radiolarian siltstone }\end{array}$} \\
\hline \multicolumn{4}{|l|}{ Campanian-M. Albian } \\
\hline Unit VI & $2.18-3.2$ & $0.09-0.14$ & 303 \\
\hline \multicolumn{4}{|l|}{ Volcaniclastic debris } \\
\hline M. Albian-L. Aptian & & & \\
\hline
\end{tabular}

and which tend to obscure details below them (Fig. 4) are interpreted to be lava flows and sills. Similar flows have been described for the Ontong Java Plateau by Stoeser (1975) and Kroenke (1972). If the sills in Unit II originated from Ita Mai Tai then the edifice must have been active during the deposition of Unit II. Unit VI is interpreted by the authors of this paper to be the main edifice building deposit because it is composed of volcanogenic sediments. The layer that lies on top of Unit II at Site 585 has also been interpreted as volcanogenic in origin, probably from other seamounts such as the one to the north.

Profile C-C' (Fig. 5) crosses the southeastern basin. The width of the basin along track is approximately $100 \mathrm{~km}$. This basin appears to be much shallower than the other, extending to only 8.4 seconds, or about $6300 \mathrm{~m}$. Total sediment thickness contained in the south-

TABLE 2. Pelagic Cap Velocities, Traveltines, Thicknesses

\begin{tabular}{lccc}
\hline & $\begin{array}{c}\text { Velocity } \\
(\mathrm{km} / \mathrm{s})\end{array}$ & $\begin{array}{c}\text { Traveltime } \\
(\mathrm{s})\end{array}$ & $\begin{array}{c}\text { Maximum } \\
\text { Thickness } \\
(\mathrm{m})\end{array}$ \\
\hline Pelagic cap & 1.63 & 0.07 & 114 \\
Oolitic limestone & 3.83 & 0.01 & 35 \\
Lagoonal mud & 2.00 & 0.04 & 80 \\
\hline
\end{tabular}



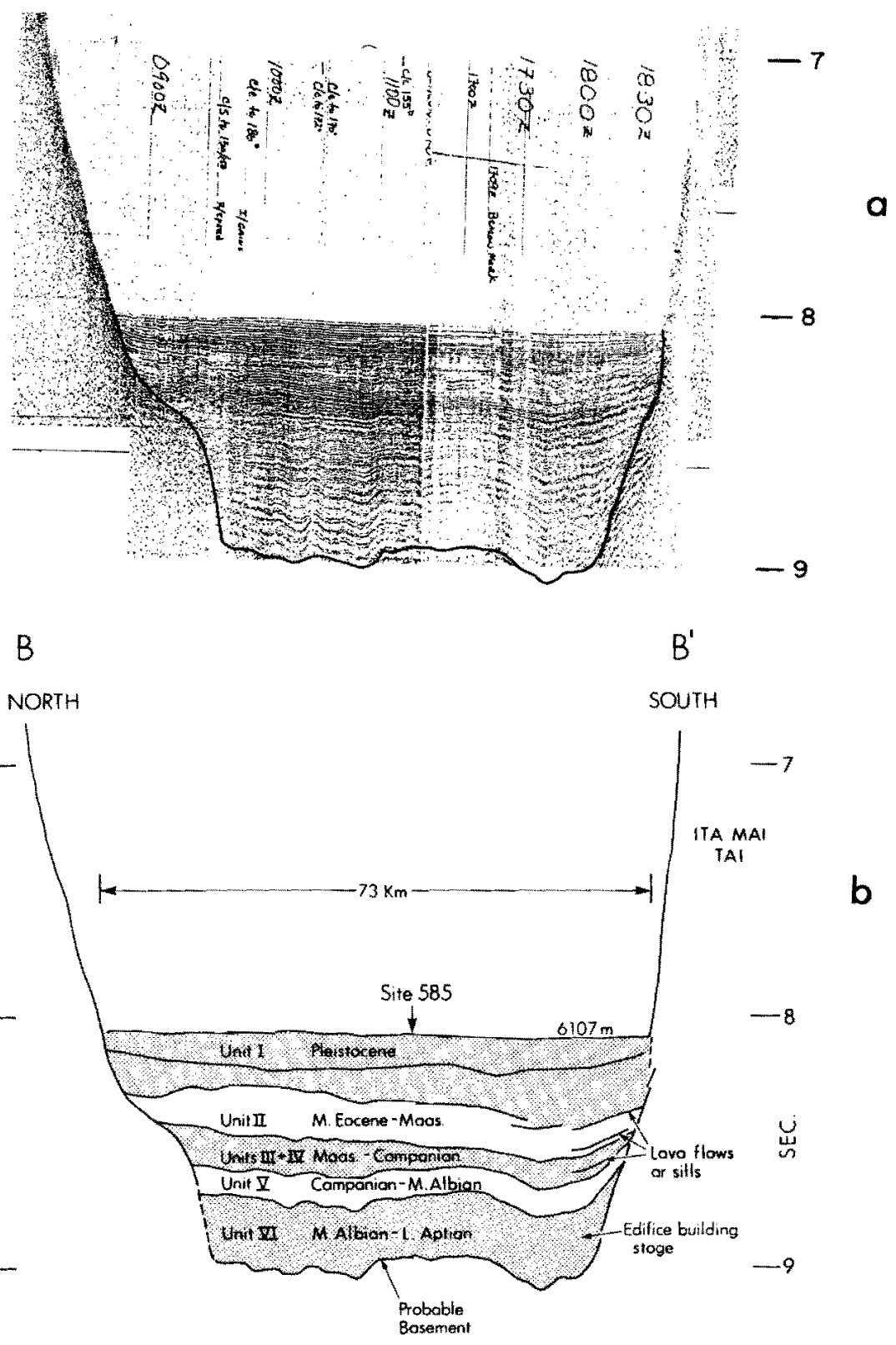

Fig. 4. Photo of airgun seismic reflection record of basin to the north of Ita Mai Tai (Glomar Challenger, Leg 89 profile).

(b) Line drawing showing units from Site 585 drilling record, and locations of proposed lava flows and sills.

eastern basin is about $300 \mathrm{~m}$ as opposed to $900 \mathrm{~m}$ in the northern basin. Again, there is evidence for sills near 8.3 seconds. However, these, and the bright reflector extending across the basin between 8.1 and 8.2 seconds of reflection time, may be obscuring the depth to true basement. Models for these scenarios are described in a following section. Several diapiric or piercement structures extend upward from the basement. One, in fact, stands above the surrounding sediments on the seafloor. These may be intrusive volcaniform features related to the formation of the other seamounts in the vicinity. Their ages are unknown but are probably late Cretaceous because of the late Cretaceous radiometric age determinations of three other nearby seamounts (Scripps, Lamont, and Wilde) [Ozima et al., 1977].

\section{Edifice Structure}

There are five different acoustic layers or strata comprising the summit [Nemoto et al., in prep., 1986] (Fig. 6). The smooth and continuous uppermost layer is the pelagic cap which drapes the entire top of the structure except for the northernmost end and is thickest in the middle part of the profile. There is little or no sediment evident on the flanks. The second layer is a thin but bright reflector interpreted as hard oolitic limestone. This layer is sporadically distributed, apparently occuring only where the pelagic sediments are thickest. Beneath this is a series of flat-lying reflectors interpreted as lagoonal muds which are again thickest in the middle portion of 


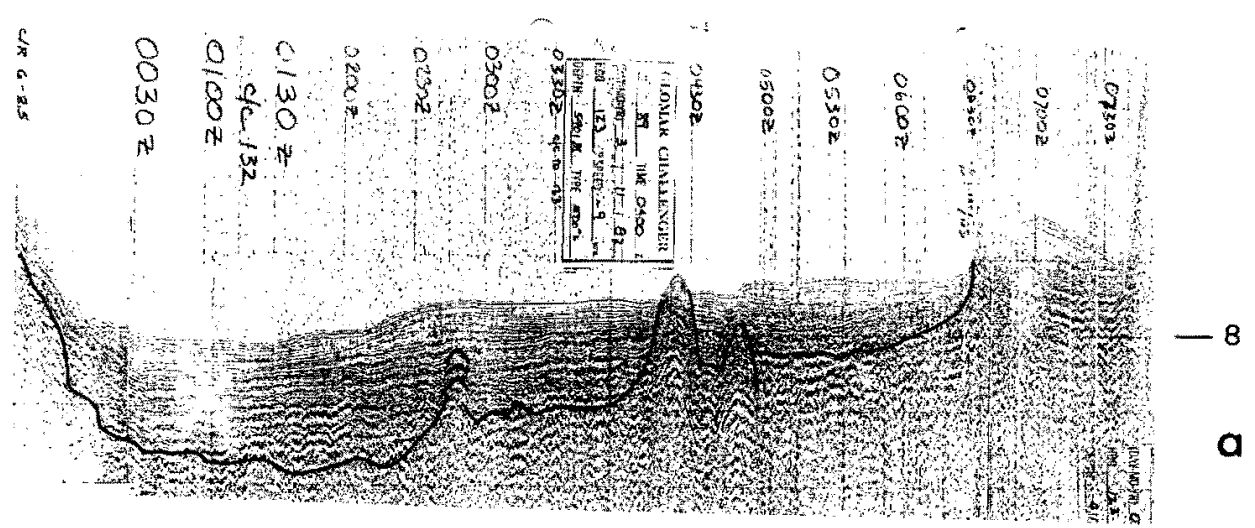

C NORTHWEST SOUTHEAST

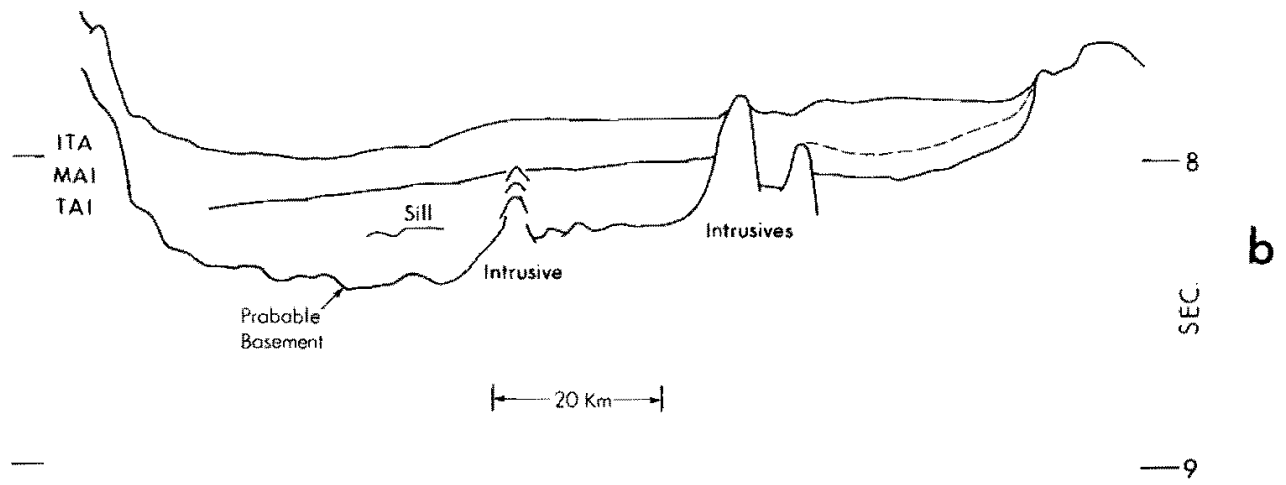

Fig. 5. Photo of airgun seismic reflection record of basin to the southeast of Ita Mai Tai (Glomar Challenger, Leg 89 profile). (b) Line drawing showing the probable depth to basement, and locations of intrusive structures.

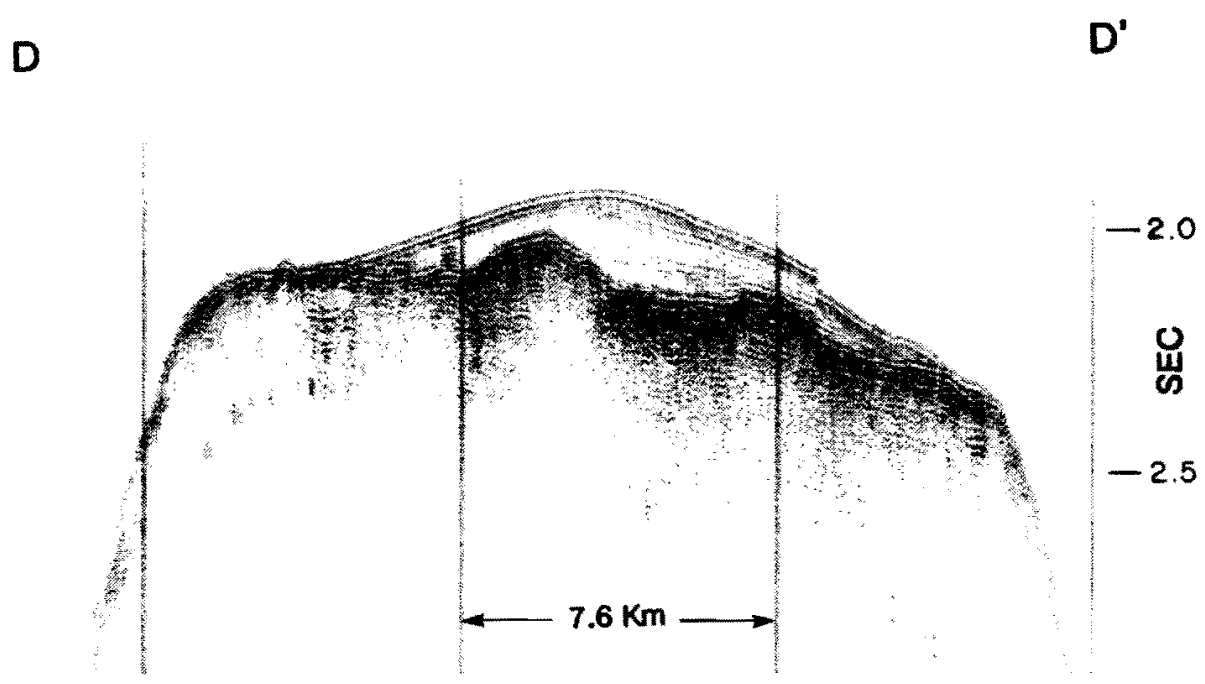

Fig. 6. Photo of airgun EPC seismic reflection record from KK810626 Leg 2 over the summit of Ita Mai Tai. This transect lies between DSDP Sites 200 and 201 (Fig. 2, along line D-D'). 


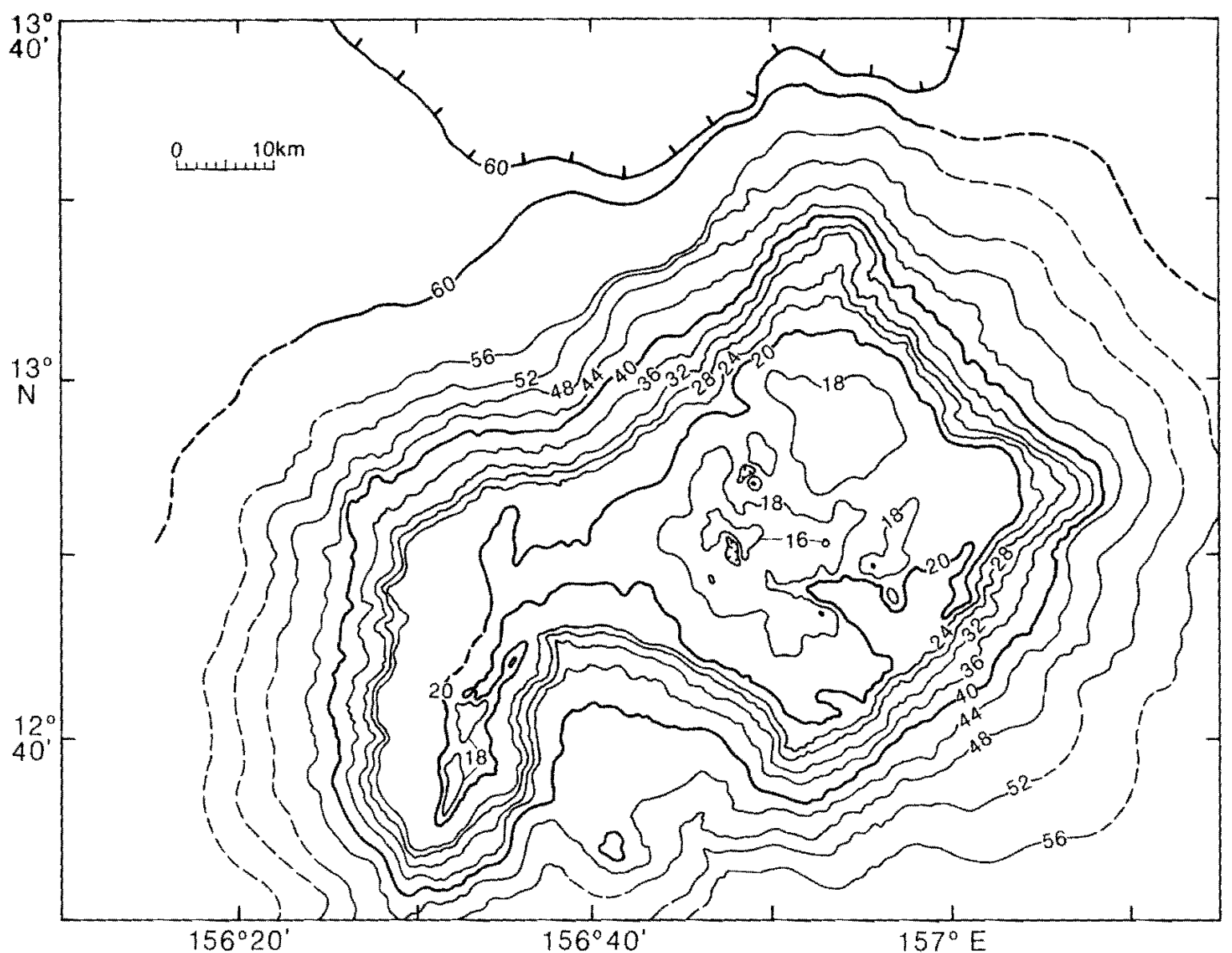

Fig. 7. Map of Ita Mai Tai showing the depth to basement. Sediment thicknesses above the volcanic basement have been removed. Contour interval is $200 \mathrm{~m}$ over the summit area, $400 \mathrm{~m}$ on the flanks.

the profile. The velocities, traveltimes, and maximum thicknesses for these uppermost three layers are given in Table 2.

The velocities of the pelagic and oolitic layers are taken from Heezen et al., (1973). The oolitic particle velocity was determined to be 3.83 $\mathrm{rm} / \mathrm{sec}$ [Heezen and MacGregor, 1973] which is in good agreement with that determined by others [Press, 1966; Furumoto et al., 1970].

The interpretations of these layers and their thicknesses (Table 2) agree very well with Jones (1973) who used sonobuoy data to compute a velocity of $1.6 \mathrm{~km} / \mathrm{sec}$ for the pelagic cap and $3.85 \mathrm{~km} / \mathrm{sec}$ for the colitic limestone. Below the lagoonal mud is the irregular top of two other components, the reef complex and the volcanic basement. The reef is not continuous across the profile but is indicated only on the flanks where the reef community grew around the edges of the lagoon. The maximum thickness of the reef is 0.1 second of reflection time. The velocity as calculated by the method of Gregory and Kroenke (1982) ranges from $3.0-4.1 \mathrm{~km} / \mathrm{sec}$, giving a thickness of $150-205 \mathrm{~m}$.

The in regularity of the volcanic basement is probably due to erosion before the seamount became an atoll. It a Mai Tai must have subsided a total of $2090 \mathrm{~m}$ which is comparable to other seamounts in the area such as Kwajalein $(2000 \mathrm{~m})$ and Enewetak $(1900 \mathrm{~m})$ [Jones, 1973]. Subsidence apparently was fast enough so that the seamount was not completely leveled, but not fast enough to prevent reefs and a lagoon from forming for a short time. The basement map [Nemoto et al., in prep., 1986] (Fig. 7) shows the aerial extent of the erosional remnants of the original volcano. It is not difficult to imagine looking at an aerial photo of a present day analog, Tahiti for example, and seeing the volcanic remnants standing above the lagoon and the fringing barrier reef.

The foregoing interpretations of the seismic reflection records are based on copies of the DSDP Leg 89 analog shipboard seismic reflection records [R. Moberly, pers. comm., 1985]. Whitman (1985) has independently interpreted the digitally collected seismic data of the Leg. The essential points of our interpretations agree with hers.

The post-eruptive depositional history of Ita Mai Tai is well recorded in the drilling record from Site 202 (Fig. 2). A 75 m thick Globigerina sand and sandstone of middle Eocene and early Pliocene age overlies $35 \mathrm{~m}$ of lagoonal oolitic limestone of indeterminate age. Below this is a layer of lagoonal coraliferous mud at least $45 \mathrm{~m}$ thick containing a few fragments of basalt and feldspar indicating that the volcanic basement is close to outcropping in this area [Heezen et al, 1973; Hesse, 1973].

Neither the reef complex nor the basement were directly sampled in any of the DSDP holes. However, a number of dredges taken by the $\mathrm{R} / \mathrm{V}$ Kana Keoki in 1981 did sample the reef outcrop, the lagoonal deposits, as well as slump or terrace deposits.

\section{Gravity}

The configuration of the free-air gravity anomaly over the seamount is shown in Figure 8. Generally, the shape of the anomaly follows the 

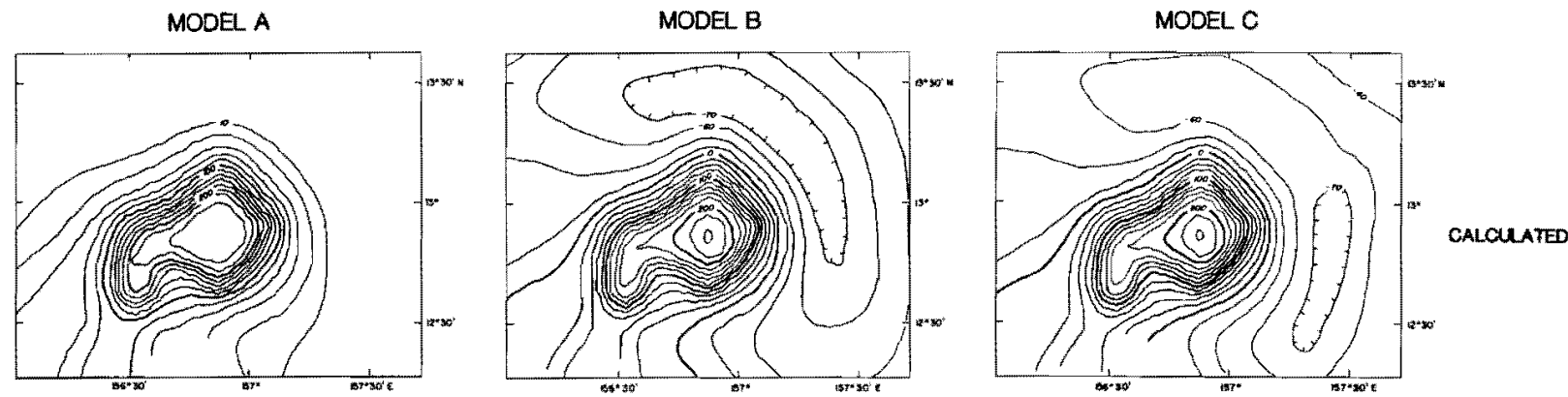

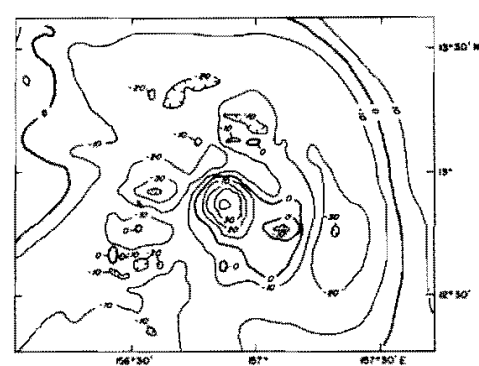

(a)

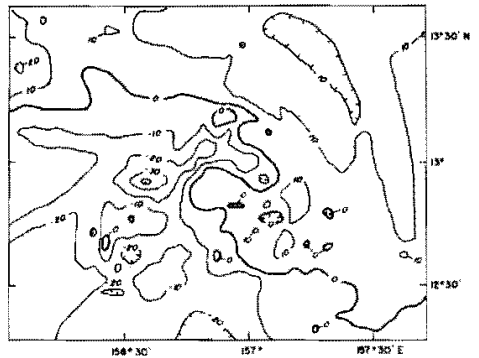

(b)

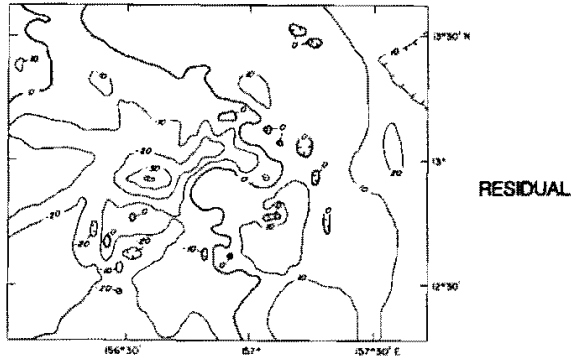

(c)

Fig. 11. Calculated and residual (observed minus calculated) gravity fields in mgal for models $A, B$ and $C$.
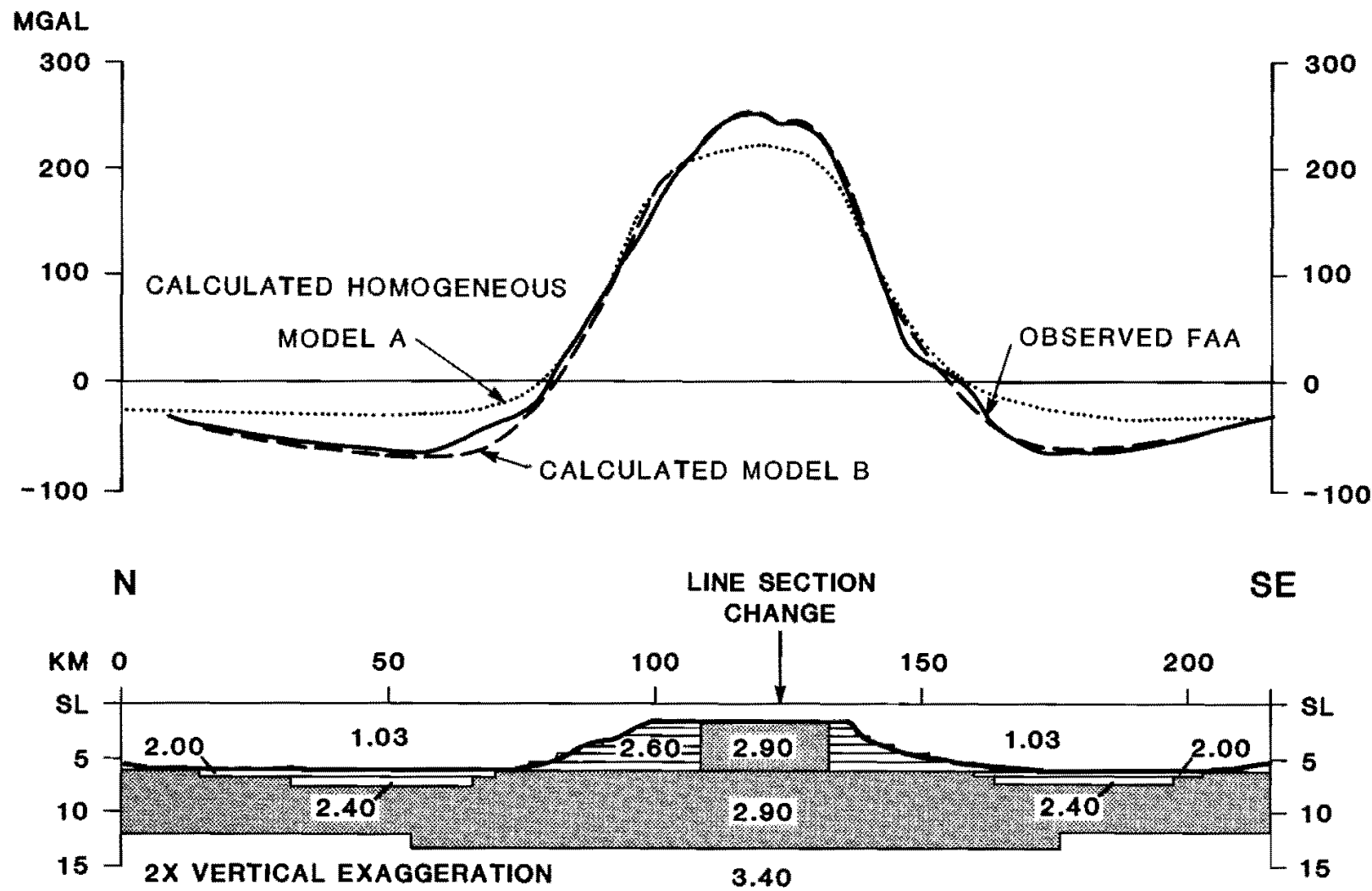

Fig. 12. (a) Cross-section of the observed gravity anomaly (solid line), calculated values for model $B$ (dashed line), and laterally homogeneous model A (dotted line). (b) Cross-section showing the density prisms used in model B. A volcanic conduit, sediment bodies, and crustal thickening were added. Location of transect shown in Figure 10. 

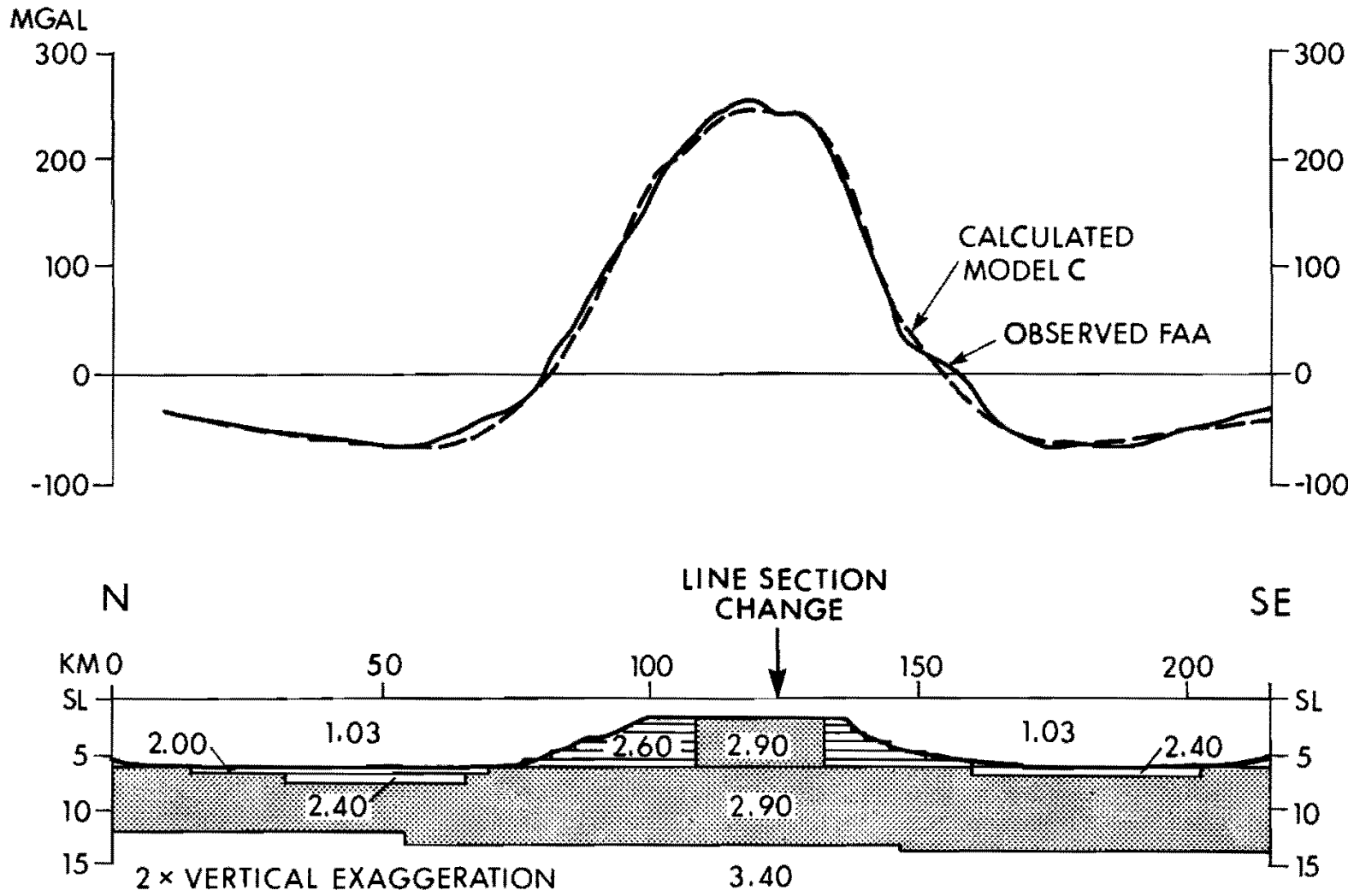

Fig. 13. Same as Figure 12, using model C. Extended crustal thickening toward the southeast.

directly below the seamount (Fig. 12b). The crust-mantle density contrast was assumed to be $0.5 \mathrm{~g} / \mathrm{cm}^{3}$.

To achieve the final models, two slightly different approaches were used to achieve the final models. Model $B$ assumes identical sediment bodies to the north and southeast (Fig. 12b), although the southeastern basin was not directly sampled, and $1.0 \mathrm{~km}$ of crustal thickening beneath the seamount (body 12, Fig. 10b). The calculated and residual anomalies are shown in Figure $11 \mathrm{~b}$. The maximum difference between the observed and calculated along the northern track is about $25 \mathrm{mgal}$. A cross sectional profile of the observed and the calculated gravity anomalies is shown in Figure 12a. The goodness of fit parameter is 4.87 [Richards et al., 1967], showing that the model adequately describes the observed anomaly.

Model $\mathrm{C}$ is very similar to model $\mathrm{B}$ except that there is one less sediment body in the sontheastern basin, indicating a shallower depth to acoustic basement, and crustal thickening of $1.5 \mathrm{~km}$ which extends casterly to the edge of the model (Fig. 13b). The plan view of the prisms is shown in Figure 10c. Figures $1 \mathrm{ic}$ and 13a show the calculated and residual anomalies. Like model $B$, the maximum residual is about $25 \mathrm{mgal}$, along the northern track. The goodness of fit is 4.96 , slightly better than model $B$.

The difference between the two models' calculated anomalies is negligible. Both adequately explain the observed data. The seismic data however would seem to give more credibility to model $\mathrm{C}$ with its shallower southeast basin, because it does not require that opaque layers (lava flows, sills, etc.) mask deeper sediments. However, model $\mathrm{C}$ does require the assumption of an abrupt change in crustal thickness.

Thus, Ita Mai Tai appears to be almost completely uncompensated locally. This rather dense seamount is, in effect, perched on oceanic crust 6-7.5 km thick causing at most only $1.5 \mathrm{~km}$ of crustal downwarping. The lack of isostatic compensation in Ita Mai Tai may be the result of mid-plate eruption on thick inelastic lithosphere with little or no sill injection into the crust.

\section{Conclusions}

Ita Mai Tai first erupted during the Aptian/Albian and possibly again during the Eocene. The volcanism is recorded in volcaniclastic deposits in the basins north and southeast of Ita Mai Tai. Gravity models suggest that Ita Mai Tai is a large locally uncompensated seamount that only requires an addition of $1.5 \mathrm{~km}$ of crustal thickening. As the oceanic lithosphere moves away from the ridge crest, it cools and thickens so that its effective elastic thickness is increased (Watts and Ribe, 1984). Mid-plate seamounts formed on old seafloor are often associated with long wavelength, high amplitude gravity anomalies, thick effective elastic thicknesses, and the absence of local isostatic compensation. Kellogg et al. (this volume) described an empirical equation relating isostatic compensation and the age of loading $t$ (MyBP) of seamounts:

$$
\text { Compensation }(\%)=68-5.6 \mathrm{t}^{0.5}
$$

Thus, the lack of local compensation $(10 \%+13 \%$, J. Freymueller and J. Kellogg, in prep.) probably resulted from eruption on thick oceanic lithosphere that was at least 30-40 m.y. old and perhaps $100 \mathrm{~m} . \mathrm{y}$. old. In other words, the oceanic crust under Ita Mai Tai is probably early Jurassic to early Cretaceous in age. 
Acknowledgements. The authors wish to acknowledge the contributions of several individuals who greatly aided the success of this project. They include Frisbee Campbell for the initial data collection and unpublished bathymetry, Loren Kroenke and Kenji Nemoto for unpublished seismic reflection records and stratigraphic interpretations, and J. Marsh for an unpublished Seasat-Geos-3 gravity image (Fig. 1). The paper was improved with comments from John Rose, Al Rudman, and an anonymous reviewer. This study was supported by the Office of Naval Research, Code 425GG. Hawaii Institute of Geophysics contribution no. 1845 .

\section{References}

Batiza, R., Abundances, distribution and sizes of volcanoes in the Pacific Ocean and implications for the origin of non-hotspot volcanoes, E.P.S.L., 60, 195-206, 1982.

Gregory, A. E., III, and L. W. Kroenke, Reef development in a midoceanic island; reflection profiling studies of the 500-meter shelf south of Oahu, AAPG Bull., 66, 843-859, 1982.

Furumoto, A. S, J. F. Campbell, and D. M. Hussong, Seismic studies of subsurface structure in the Ewa coastal plain, Oahu, Hawaii, Pacific Sci, 24, 529-542, 1970.

Heezen, B. C. et al., Tertiary pelagic ooze on Ita Maitai guyot; equatorial Pacific: DSDP sites 200 and 201, in Initial Reports of the Deep Sea Drilling Project, vol. 20, edited by B. C. Heezen and I. D. MacGregor, pp. 87-96, U.S. Government Printing Office, Washington, D.C., 1973 .

Heezen, B. C., MacGregor, I. D., Oolitic limestone on the Ita Maitai Guyot, Equatorial Pacific: DSDP Site 202, in Initial Reports of the Deep Sea Drilling Project, vol. 20, edited by B. C. Heezen and I. D. MacGregor, pp. 97-102, U. S. Government Printing Office, Washington, D.C., 1973.

Hesse, R., Diagenesis of a seamount oolite from the west Pacific, Leg 20, DSDP, in Initial Reports of the Deep Sea Drilling Project, vol 20, edited by B. C. Heezen et al., pp. 363-387, U.S. Government Printing Office, Washington, D.C., 1973.

Hilde, T. W. C., N. Isezaki, and J. M. Wageman, Mesozoic sea-floor spreading in the North Pacific, in The Geophysics of the Pacific Ocean Basin and its Margin, Geophys. Monogr. Ser., vol. 19, edited by G. H. Sutton, M. H. Manghnani, and R. Moberly, pp. 205-226, Amer. Geophys. Union, Washington, D. C., 1976.

Hilde, T. W. C., S. Uyeda, and L. Kroenke, Evolution of the western Pacific and its margin, Tectonophysics, 38, 145-165, 1977.

Jones, E. J. W., Determination of sedimentary velocities using expendable sonobuoys at DSDP Leg 20 drilling sites, northwest $\mathrm{Pa}$ cific, in Initial Reports of the Deep Sea Drilling Project, vol. 20, edited by B. C. Heezen and I. D. MacGregor, pp. 625-642, U. S. Government Printing Office, Washington, D. C., 1973.

Jordan, T. H., H. W. Menard, and D. K. Smith, Density and size distribution of seamounts in the eastern Pacific inferred from widebeam sounding data, J. Geophys. Res., 88, 10508-10518, 1983.

Kellogg, J. N., and I. J. Ogujiofor, Gravity field analysis of Sio Guyot: An isostatically compensated seamount in the Mid-Pacific Mountains, Geo-Marine Letters, 5, 91-97, 1985.

Kellogg, J. N., B. S. Wedgeworth, and I. J. Ogujiofor, Invited $\mathrm{Pa}$ per, Three-dimensional modeling of the gravity fields of seamounts, Abst., SEG/USN Tech. Symposium on 3-Dimensional Marine Data Collection, Processing, Interpretation, and Presentation, NSTL, Miss., p. 9, 1984.

Kellogg, J. N., B. S. Wedgeworth, and J. Freymueller, Isostatic compensation and conduit structures of Western Pacific Seamounts: Results of three-dimensional gravity modeling, this volume.

Kroenke, L. W., Geology of the Ontong Java Plateau, Hawaii Institute of Geophysics Report 72-5, Honolulu, Hawaii, pp. 1-119, 1972.

Larson, R. L., Late Jurassic and Early Cretaceous evolution of the western central Pacific Ocean, J. Geomag. Geoelectr. 28, 219-236, 1976 .
Larson, R. L., and C. G. Chase, Late Mesozoic evolution of the westen Pacific Ocean, GSA Bull., 83, 3627-3644, 1972.

Le Pichon, X., and M. Talwani, Crustal structure of the mid-ocean ridges; 1, Seismic refraction measurements, J. Geophys. Res., 70, 319-339, 1965.

Lonsdale, P., and F. N. Spiess, A pair of young cratered volcanoes on the East Pacific Rise, J. of Geology, 87, 157-173, 1979.

Menard, H. W., Marine Geology of the Pacific, 271 pp., McGraw-Hill, New York, 1964.

Menard, H. W., Darwin reprise, J. Geophys. Res., 89, 9960-9968, 1984.

Ozima, M., M. Honda, and K. Saito, ${ }^{40} \mathrm{Ar}^{39} \mathrm{Ar}$ ages of guyots in the western Pacific and discussion of their evolution, Geophys. J. Roy. Astr. Soc., 51, 475-485, 1977.

Plouf, D., Gravity and magnetic fields of polygonal prisms and application to magnetic terrain corrections, Geophysics, 41, 727-741, 1976.

Press, F., Seismic velocities, in Handbook of Physical Constants, edited by S. P. Clark, Jr., pp. 202-203, Geol. Soc. America Mem. 97, 1966.

Richards, M. L., V. Vacquier, and G. D. van Voorhis, Calculation of the magnetization of uplifts from combining topographic and magnetic surveys, Geophysics, 32, 678-707, 1967.

Rose, J. C., and B. R. Bowman, The effect of seamounts and other bottom topography on maxine gravity anomalies, in Proceedings of the International Symposium on Applications of Marine Geodesy, pp. 381-396, Mar. Tech. Sor., Washington, D. C., 1974.

Sager, W. W., G. T. Davis, B. H. Keating, and J. A. Philpotts, A geophysical and geologic study of Nagata Seamount, northern Line Islands, J. Geomag. Geoelectr., 34, 283-305, 1982.

Schimke, G. R., and C. G. Bufe, Geophysical description of a Pacific Ocean seamount, J. Geophys. Res., 79, 559-569, 1968.

Schlanger, S. O., and I. Premoli-Silva, Tectonic, volcanic and paleographic implications of redeposited reef faunas of late Cretaceous and Tertiary age from the Nauru Basin and Line Islands, in Initial Reports of the Deep Sea Drilling Project, vol. 61, edited by R. L. Larson et al., pp. 817-827, U. S. Government Printing Office, Washington, D. C., 1981.

Scientific Party, Leg 89, Leg 89 drills Cretaceous volcanics, Geotimes, $28,17-20,1983$.

Shipley, T. H., J. M. Whitman, F. K. Duennebier, and L. D. Petersen, Seismic stratigraphy and sedimentary history of the East Mariana Basin, western Pacific, Earth Planet. Sci. Lett., 64, 257-275, 1983.

Stoeser, D. B., Igneous rocks from Leg 30 of the Deep Sea Drilling Project, in Initial Reports of the Deep Sea Drilling Project, vol. 30, edited by J. E. Andrews, G. Peckham, et al., Pp. 401-414, U. S. Government Printing Office, Washington, D. C., 1975.

Talwani, M. and M. Ewing, Rapid computation of gravitational attraction of three-dimensional bodies of arbitrary shape, Geophysics, 25, 203-225, 1960.

Udintsev, G. B. et al., Seamounts of the Pacific Ocean, in Volcanoes and Tectonosphere, edited by H. Aoke and S. Iizuka, pp. 7-33, Tokai University Press, Shimizu, Japan, 1976.

Watts, A. B. and N. M. Ribe, On geoid heights and flexure of the lithosphere at seamounts, $J_{v}$ Geophys. Res., 89, 11152-11170, 1984.

Watts, A. B., U. S. ten Brink, P. Buhl, and T. M. Brocher, A multichannel seismic study of lithospheric flexure across the HawaiianEmperor seamount chain, Nature, 315, 105-111, 1985.

Whitman, J. M., Tectonic and bathymetric evolution of the Pacific ocean basin since $74 \mathrm{Ma}$, M.S. thesis, $168 \mathrm{pp}$., Univ. of Miami, Coral Gables, Dec. 1981.

Woollard, G. P., The relation of gravity anomalies to surface elevation, crustal structure and geology, Research Report Series No. $62-9,330 \mathrm{pp}$., Aeronautical Chart and Information Center, United States Air Force, St. Louis, Missouri, 1962. 